Mol2Net-04, 2018, BIOCHEMPHYS-01 (pages 1- x, type of paper, doi: xxx-Xxxx http://sciforum.net/conference/mol2net-4

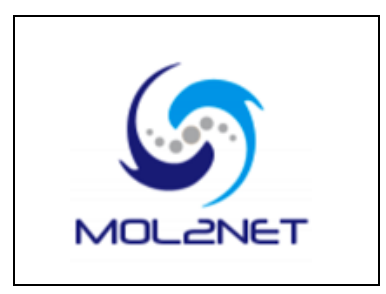

SciForum Mol2Net-04

\title{
Synthesis of some new diarylmethanes by McMurry coupling reaction: characterization and antibacterial activity
}

\author{
Ameni Hadj Mohamed* 1,2, Meral Görmen ${ }^{1}$, Mehdi El Arbi ${ }^{3}$, Moncef Msaddek ${ }^{2}$, Maité Sylla- \\ Iyarreta Veitía*1 \\ 1 Equipe de Chimie Moléculaire, Laboratoire Génomique, bioinformatique et chimie moléculaire \\ GBCM, EA 7528, Conservatoire national des arts et métiers, 2 rue Conté, 75003, Paris France; \\ HESAM Université maite.sylla@lecnam.net, amenihajmohamed@gmail.com \\ 2 Laboratoire de Chimie Hétérocyclique, Produits Naturels et réactivité (LR11ES39). Faculté des \\ Sciences de Monastir, Université de Monastir, Boulevard de l'Environnement, 5019, Monastir, \\ Tunisie; moncefmsadek@gmail.com \\ 3 Laboratoire de Biotechnologie microbienne et d'ingénierie des enzymes (LBMIE). Centre de \\ Biotechnologie de Sfax, Université de Sfax, Route de Sidi Mansour Km 6, BP 1177, 3018 Sfax, \\ Tunisie; mehdi_arbi@yahoo.fr \\ 4 *Author to whom correspondence should be addressed; E-Mail: maite.sylla@lecnam.net \\ amenihajmohamed@gmail.com, Tel.: +33-1-58 808482
}

Received: / Accepted: / Published:

\begin{abstract}
Diarylmethanes (DAMs) and triarylmethanes (TAMs), molecules bearing two or three aryl groups (phenyls or heterocycles) bonded to a central carbon atom, have numerous applications. The biological and therapeutic relevancy of this class of molecules has been demonstrated for various applications in the field of antimicrobials, infectious, cardiovascular and nervous system disorders, genital tract diseases, estrogen-related disorders and bone remodeling. These interesting compounds have also been used as starting materials for the development of high value-added molecules. We report here the synthesis of two new diarylmethanes using a McMurry coupling reaction as well as their antibacterial evaluation.
\end{abstract}

Keywords: diarylmethanes, triarylmethanes, McMurry coupling reaction, antibacterial activity.

\section{Introduction}

Di- and tri-arylmethanes have attracted much attention as a result of their unique structural and physical properties and applications in organic chemistry and as interesting scaffolds presented in biological active compounds [1-2].
The feature of triarylmethane compounds comes from the three aryl groups bonded to a sp3 hybridized central carbon atom bearing a hydrogen atom. Compounds containing two aryl groups connected by a single carbon atom are considered as diarylmethanes. 
Triarylmethane scaffolds are biological and therapeutical relevancy in several areas such as antimicrobials, anticancer cardiovascular and nervous system disorders and bone remodeling. They have been used as like leuco dyes, $\mathrm{pH}$ indicators, photochromic agents, fluorescent probes and they also have many applications in materials science [1-7].

Diarylmethanes based derivatives have played an essential role in the development of supramolecular chemistry and specially in the synthesis of supramolecular compounds like calixarenes and pillararenes. Furthermore, diarylmethanes have shown a major role in medicinal chemistry as $\mathrm{GABA}_{\mathrm{A}}$ receptor modulators [8], anticancer and antibacterial compounds [9-10].

Diarylmethane scaffold is mainly obtained by Friedel-Crafts alkylation of the corresponding benzyl alcohols with another arene, metalcatalyzed cross coupling of aryl halides with benzyl nucleophiles, metal catalyzed cross coupling of benzyl halides with aryl nucleophiles and $\mathrm{C}-\mathrm{C}$ bond formation between tosyl hydrazones and aryl boronic acids [1].

Considering this perspective, we presented in this paper the synthesis of two diarylmethanes using a McMurry cross coupling reaction. This coupling procedure has acquired great importance in organic synthesis particularly in the preparation of sterically hindered alkenes through homocouplings and in the construction of cycloalkenes with ring sizes ranging from 3 to 72 via intramolecular couplings. The utility of McMurry coupling reaction have been also highlighted as the key step in numerous syntheses of natural products [11].

We describe herein the synthesis of two new diarylmethanes derivatives: 4-methoxyphenyl-2arylvinyl-pyridine and its ferrocenyl analogue and the preliminary evaluation of their antibacterial activity.

\section{Results and Discussion}

\subsection{Synthesis of diarylmethanes}

Diarylmethanes were prepared via a McMurry coupling reaction. General synthetic methods to obtain the target compounds are outlined in Scheme 1. The first detailed synthesis has been described by Sylla-I-V and co-workers in 2015 .

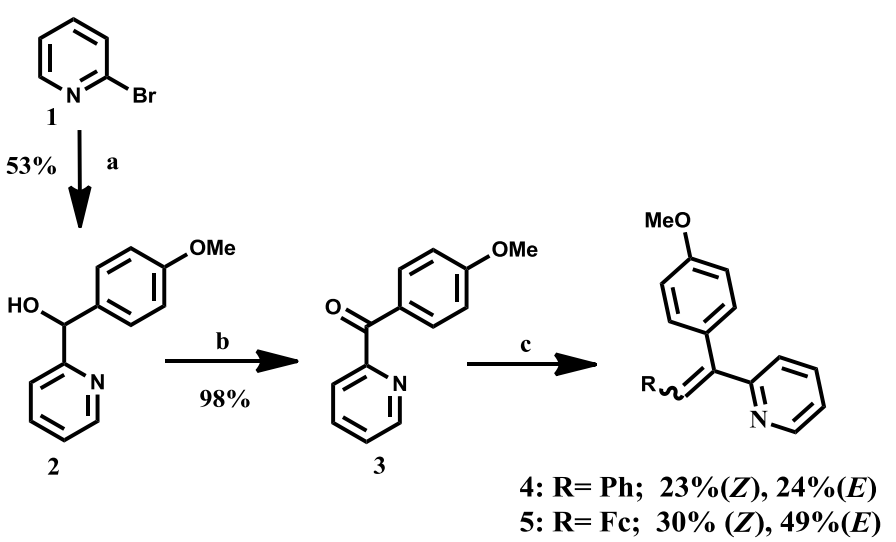

Scheme 1: Synthesis of diarylmethanes (a): $n$ BuLi, $p$-anisaldehyde, THF, $-78^{\circ} \mathrm{C} /$ r.t., 17 h; (b): $\mathrm{NaOH}, \mathrm{O}_{2}$, toluene, reflux, $18 \mathrm{~h}$; (c): $\mathrm{TiCl}_{4}, \mathrm{Zn}$, THF, reflux, $2 \mathrm{~h}$ then the corresponding aldehyde, 8-10 min.

The (4-methoxyphenyl)(pyridin-2-yl)methanol 2 has been prepared by a lithium-bromine exchange following the procedure described by Seto et al. 2004 [12], from 2-bromopyridine and $p$ anisaldehyde in anhydrous THF. The desired carbinol 2 was isolated in 53\% yield. This average yield could be explained to a certain extent by the formation of the by-product $\mathbf{6}$ formed by the reaction of 2-bromopyridine with two molecules of $p$-anisaldehyde (Figure 1).

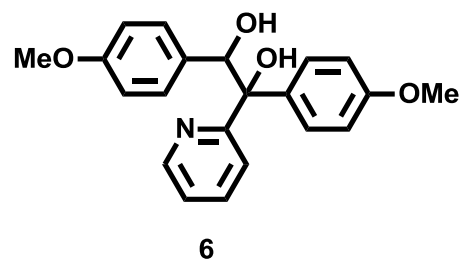

Figure 1: The diol 6 formed during the lithiumbromine exchange reaction.

The aryl ketone $\mathbf{3}$ was synthesized from the carbinol 2 in excellent yield (98\%) via a basepromoted aerobic oxidation using air as a free and clean oxidant $[12,13]$. The key step to obtain the desired olefin intermediates involved a McMurry cross-coupling reaction between the ketone $\mathbf{3}$ and the corresponding aldehydes (benzaldehyde or ferrocenecarboxaldehyde) to afford the desired compounds $\mathbf{4}$ and $\mathbf{5}$ in two separable $E$ and $Z$ isomers $(24 \%$ and $23 \%$ yields respectively for compound 4 and $30 \%$ and $49 \%$ yields respectively for compound 5). After the preparation of the $\mathrm{Zn} / \mathrm{TiCl}_{4}$ suspension, the reaction occurs in 8 to 10 minutes. Nevertheless, the yields can decrease because of the probable competition between the 
formation of the desired cross-coupled product and the two homo-coupled compounds [14].

\subsection{Biological studies}

Compounds $\mathbf{4}$ and $\mathbf{5}$ were screened for antibacterial activity against Gram-positive and Gram-negative pathogens. Gram-positive strains Micrococcus luteus, Staphylococcus aureus and Listeria monocytogenes, Gram-negative strains Escherichia coli, Enterococcus faecalis and Salmonella enterica were used for inhibitory tests, using doxycycline, a broad spectrum antibiotic, as a control. The minimal inhibitory concentration (MIC) and minimal bactericidal concentration (MBC) values for all compounds are presented in Table 1. The MIC and MBC values for doxycycline were found to be $<12.5 \mu \mathrm{g} / \mathrm{mL}$ and $12.5 \mu \mathrm{g} / \mathrm{mL}$ on Staphylococcus aureus.

As depicted in Table 1, compounds 4 and 5 displayed an excellent antimicrobial activity. The tested compounds seem to be more bactericidal than bacteriostatic, since the $\mathrm{MBC} / \mathrm{MIC}$ ratio is less than or equal to four $(\leq 4)$ [15]. No significant difference for antimicrobial activity was observed against Gram-positive or Gram-negative bacteria between $E$ and $Z$ isomers of $\mathbf{4}$ and $\mathbf{5}$. However, for both compounds, $\mathrm{Z}$ isomers seem to be more active than their $E$ analogues. For instance, isomer 4b displayed MIC values between [6,25-12.5] $\mu \mathrm{g} / \mathrm{mL}$ against Listeria, E. Coli and Salmonella whereas its isomer $4 a$ showed MIC values between [12.5-25] $\mu \mathrm{g} / \mathrm{mL}$ against the same pathogens. For compound $\mathbf{5}$, the $Z$ isomer $\mathbf{5 b}$ exhibited MIC values between [12.5-25] $\mu \mathrm{g} / \mathrm{mL}$ against Micrococcus, Staphylococcus and E. Coli versus [25-50] $\mu \mathrm{g} / \mathrm{mL}$ for the $E$ isomer 5a. These results suggest that the spatial arrangement of the molecule may play an important role in biological activity as it may be favorable in the interaction with biological receptors.

As shown in Table 1 the $Z$ isomer $\mathbf{4 b}$ showed better activity than its ferrocenyl analogue $\mathbf{4 a}$ with MIC values between [6.25-12.5] $\mu \mathrm{g} / \mathrm{m}$ against Gram-positive strains Listeria and Gram-negative strains Escherichia coli, and Salmonella versus [25-50] $\mu \mathrm{g} / \mathrm{mL}$; similar results for $\mathrm{Z}$ isomer $\mathbf{5 b}$ were obtained ([12,5-25] $\mu \mathrm{g} / \mathrm{mL},[25-50] \mu \mathrm{g} / \mathrm{mL}$ respectively). In the case of Gram-positive strains Micrococcus and Staphylococcus and Gramnegative strains Enterobacterium the results are equivalents. These results could suggest that a ferrocenyl moiety may not be necessary to achieve excellent antimicrobial activity.

Table 1. Antimicrobial activities of compound 4 and its ferrocenyl analogue 5. Minimal inhibitory concentration (MIC) and minimal bactericidal concentration (MBC) in $\mu \mathrm{g} / \mathrm{mL}$.

\begin{tabular}{|c|c|c|c|c|c|c|c|c|}
\hline \multirow{2}{*}{$\begin{array}{l}\text { Cpd. } \\
\text { Num }\end{array}$} & & & \multicolumn{3}{|c|}{$\operatorname{Gram}(+)$} & \multicolumn{3}{|c|}{ Gram (-) } \\
\hline & & & Micrococcus & Staphylococcus & Listeria & E. Coli & $\begin{array}{l}\text { Entero } \\
\text { bacterium }\end{array}$ & Salmonella \\
\hline \multirow[t]{2}{*}{$4 a$} & E isomer $\mathrm{R}=\mathrm{Ph}$ & MIC & {$[12,5-25]$} & {$[6,25-12,5]$} & {$[12,5-25]$} & {$[12,5-25]$} & {$[12,5-25]$} & {$[12,5-25]$} \\
\hline & & MBC & 50 & $>100$ & 50 & $>100$ & $>100$ & $>100$ \\
\hline \multirow[t]{2}{*}{$4 b$} & $Z$ isomer $\mathrm{R}=\mathrm{Ph}$ & MIC & {$[12,5-25]$} & {$[12,5-25]$} & {$[6,25-12,5]$} & $\begin{array}{c}{[6,25-} \\
12,5]\end{array}$ & {$[25-50]$} & {$[6,25-12,5]$} \\
\hline & & $\mathrm{MBC}$ & 100 & $>100$ & 50 & $>100$ & $>100$ & 50 \\
\hline \multirow[t]{2}{*}{$5 a$} & E isomer $\mathrm{R}=\mathrm{Fc}$ & MIC & [25-50] & {$[25-50]$} & {$[25-50]$} & {$[25-50]$} & {$[25-50]$} & [12.5-25] \\
\hline & & MBC & $>100$ & 100 & $>100$ & $>100$ & $>100$ & $>100$ \\
\hline \multirow[t]{2}{*}{$5 b$} & $Z$ isomer $\mathrm{R}=\mathrm{Fc}$ & MIC & [12.5-25] & [12.5-25] & {$[25-50]$} & [12.5-25] & {$[25-50]$} & {$[25-50]$} \\
\hline & & $\mathrm{MBC}$ & 100 & $>100$ & 50 & $>100$ & $>100$ & 50 \\
\hline \multirow{2}{*}{\multicolumn{2}{|c|}{ Doxycycline }} & MIC & - & $<12.5$ & - & - & - & - \\
\hline & & MBC & - & 12.5 & - & - & - & - \\
\hline
\end{tabular}




\section{Materials and Methods Experimental}

\section{Materials:}

All reagents were obtained from commercial sources unless otherwise noted and used as received. All reactions were monitored by analytical thin layer chromatography (TLC). TLC was performed on aluminium sheets percolated silica gel plates (60 F254, Merck). TLC plates were visualized using irradiation with light at 254 $\mathrm{nm}$ or in an iodine chamber as appropriate.

\section{Physical measurements:}

The structure of the products prepared by different methods was checked by comparison of NMR, IR and MS data and by the TLC behavior. ${ }^{1} \mathrm{H}$ and ${ }^{13} \mathrm{C}$ NMR spectra were recorded on a Bruker BioSpin $\mathrm{GmbH}$ spectrometer $400 \mathrm{MHz}$, at room temperature. Chemical shifts are reported in $\delta$ units, parts per million (ppm). Coupling constants (J) are measured in hertz (Hz). Splitting patterns are designed as followed: s, singlet; d, doublet; dd, doublet of doublets; m, multiplet; br, broad; ddd: doublet of doublet of doublet. Various 2D techniques and DEPT experiments were used to establish the structures and to assign the signals. GC-MS analysis were performed with an Agilent $6890 \mathrm{~N}$ instrument equipped with a dimethyl polysiloxane capillary column $(12 \mathrm{~m} \times 0.20 \mathrm{~mm})$ and an Agilent 5973N MS detector-column temperature gradient $100-300{ }^{\circ} \mathrm{C}$ (method 160 ): $160{ }^{\circ} \mathrm{C}(1 \mathrm{~min}) ; 160{ }^{\circ} \mathrm{C}$ to $280{ }^{\circ} \mathrm{C}\left(10{ }^{\circ} \mathrm{C} / \mathrm{min}\right)$, (method 180): $180{ }^{\circ} \mathrm{C}(1 \mathrm{~min}) ; 180^{\circ} \mathrm{C}$ to $300{ }^{\circ} \mathrm{C}$ (10 $\left.{ }^{\circ} \mathrm{C} / \mathrm{min}\right)$, (method 200): $200{ }^{\circ} \mathrm{C}(1 \mathrm{~min}) ; 200$ ${ }^{\circ} \mathrm{C}$ to $300{ }^{\circ} \mathrm{C}\left(10{ }^{\circ} \mathrm{C} / \mathrm{min}\right) ; 300{ }^{\circ} \mathrm{C}$ (4 min); Infrared spectra were recorded over the 400-4000 $\mathrm{cm}^{-1}$ range with an Agilent Technologies Cary 630 FTIR/ ATR/ ZnSe spectrometer.

High-resolution mass spectra (HRMS) analyses were acquired on a LTQ-Orbitrap XL from Thermo Scientific (Thermo Fisher Scientific, Courtaboeuf, France) mass spectrometer and operated in positive ionization mode, with a spray voltage at $3.6 \mathrm{kV}$. Detection was achieved in the Orbitrap with a resolution set to 60,000 (at $\mathrm{m} / \mathrm{z}$ 400 ) and a $\mathrm{m} / \mathrm{z}$ range between $110-1200$ in profile mode. Spectrum was analyzed using the acquisition software XCalibur 2.1.
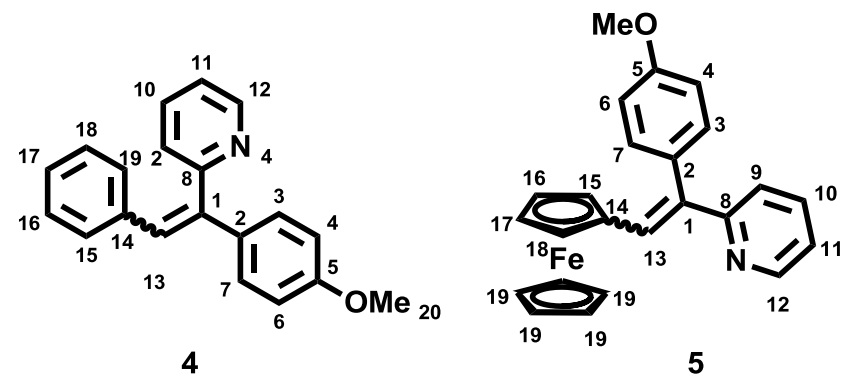

Figure 2. Convention adopted to assign signals of ${ }^{1} \mathrm{H}$ and ${ }^{13} \mathrm{C}$ spectra.

\section{4-methoxyphenyl-2-arylvinyl-pyridine 4}

To a suspension of zinc $(2.80 \mathrm{mmol}, 182 \mathrm{mg})$ in dry THF $(2.7 \mathrm{~mL})$ under argon was added dropwise $\mathrm{TiCl}_{4}(1.872 \mathrm{mmol}, 0.3 \mathrm{~mL})$. The reaction mixture was stirred during $2 \mathrm{~h}$ at $85{ }^{\circ} \mathrm{C}$. A solution of benzaldehyde $(0.487 \mathrm{mmol}, 0.05 \mathrm{~mL})$ and (4-methoxyphenyl) (pyridin-2-yl)methanone 3 $(0.468 \mathrm{mmol}, 100 \mathrm{mg})$ in THF $(1 \mathrm{~mL})$ was then added dropwise via a syringe. The reaction mixture was refluxed during $8 \mathrm{~h}$, then stirred over night at room temperature and was controlled by TLC. The reaction was cooled to room temperature and then poured into the water $(5.8 \mathrm{~mL})$ and extracted with $\mathrm{CH}_{2} \mathrm{Cl}_{2}(8 \times 9 \mathrm{~mL})$. The combined organic extracts were dried over anhydrous $\mathrm{MgSO}_{4}$, filtered and concentrated. The oily crude was purified by flash column chromatography on silica gel (cyclohexane/EtOAc 95:5) to afford the 2-(1-(4methoxyphenyl)-2-phenylvinyl) pyridine 4 in two separable $E$ and $Z$ isomers.

$E$ Isomer $4 \mathbf{a} 31.8 \mathrm{mg}$ of an orange oil $24 \%$ Yield, $\mathrm{R}_{f}=0.58 \quad \mathrm{SiO}_{2}$ (cyclohexane/EtOAc 80:20). ${ }^{1} \mathrm{H}$ NMR $\left(400 \mathrm{MHz}, \mathrm{CDCl}_{3}\right) \delta 8.65(\mathrm{~d}, \mathrm{~J}=4 \mathrm{~Hz}, 1 \mathrm{H}$, H12), $7.76(\mathrm{~s}, 1 \mathrm{H}, \mathrm{H} 13), 7.57-7.53(\mathrm{td}, \mathrm{J} 1=7.8$ $\mathrm{Hz}, \mathrm{J} 2=1.8 \mathrm{~Hz}, 1 \mathrm{H}, \mathrm{H} 9)$, 7.17- 7.09 (m, 8H, H3, H7, H11, H15, H16, H17, H18, H19), 7.02 (d, J= $8 \mathrm{~Hz}, 1 \mathrm{H}, \mathrm{H} 9$ ), 6.95-6.92 (m, 2H, H4, H6), 3.85 (s, $3 \mathrm{H}, \mathrm{H} 20, \mathrm{OMe}) \cdot{ }^{13} \mathrm{C} \mathrm{NMR}\left(100 \mathrm{MHz}, \mathrm{CDCl}_{3}\right) \delta$ 159.4(C5), 159.2 (C8), 149.2 (C12), 140.1 (C1), 137.0 (C13), 136.5 (C10), 131.5 (C3, C7), 131.3 (C2), 130.1 (C15, C19), 128.0 (C16, C18), 127.3 (C17), 122.6 (C9), 122.0 (C11), 114.5 (C4, C6), 55.3 (OMe). IR (ATR): 3061, 3029 ( $\left.v_{\mathrm{Csp} 2-\mathrm{H}}\right) ; 2922$ $\left(v_{\text {Csp3-H }}\right) ; 2857$ ( $\left.v_{\text {OMe }}\right) ; 1604,1582,1511$ and 1462 $\left(v_{\mathrm{C}=\mathrm{C}}\right) ; 1246$ ( $\left.v_{\text {asym C-O-C }}\right) ; 1031$ ( $\left.v_{\text {sym C-O-C }}\right)$. LC-MS: method FIA. $\mathrm{m} / \mathrm{z}=288[\mathrm{M}+\mathrm{H}]^{+} ; 271\left[\mathrm{M}-\mathrm{CH}_{3}\right]^{+}$. 
$Z$ Isomer 4a $31.6 \mathrm{mg}$ of an orange oil in $23 \%$ Yield, $\mathrm{R}_{f}=0.36, \mathrm{SiO}_{2}$ (cyclohexane/EtOAc 80:20). ${ }^{1} \mathrm{H}$ NMR (400 MHz, $\left.\mathrm{CDCl}_{3}\right) \delta 8.78(\mathrm{~d}, \mathrm{~J}=4 \mathrm{~Hz}, 1 \mathrm{H}$, H12), 8.12-8.08 (m, 4H, H15, H16, H18, H19), 7.66-7.62 (m, 1H, H10), 7.48-7.44(t, J=8 Hz, 3H, H3, H7, H17), 7.29-7.27( m, 1H, H11), 7.07(s, 1H, H13), 6.96-6.93 (m, 1H, H9), 6.85 (d, J= $8 \mathrm{~Hz}, 2 \mathrm{H}$, H4, H6), 3.79 (s, 3H, H20, OMe).

${ }^{13} \mathrm{C}$ NMR (100 MHz, $\left.\mathrm{CDCl}_{3}\right) \delta 159.4$ (C5), 159.1 (C8), 149.7 (C12), 140.9 (C1), 137.1 (C10), 134.4 (C14), 133.6 (C17), 133.5 (C9), 130.1 (C15, C16, C18, C19), 129.8 (C2), 129.4 (C9), 128.8 (C13), 128.5 (C3, C7), 113.9 (C4, C6), 55.3 (OMe).

IR (ATR): 3061, 3029 ( $\left.v_{\text {Csp2-H }}\right) ; 2922\left(v_{\text {Csp3-H }}\right)$; $2857\left(v_{\mathrm{OMe}}\right) ; 1604,1582,1511$ and $1462\left(v_{\mathrm{C}=\mathrm{C}}\right)$; 1246 ( $v_{\text {asym }}$ C-O-C $) ; 1031$ ( $v_{\text {sym }}$ C-O-C $) . \quad$ LC-MS: method FIA. $\mathrm{m} / \mathrm{z}=288[\mathrm{M}+\mathrm{H}]^{+} ; 575[2 \mathrm{M}+\mathrm{H}]^{+}$; $257[\mathrm{M}-\mathrm{OMe}]^{+}$.

\section{4 methoxyphenyl-2-ferrocenyl-vinylpyridine 5}

To a suspension of zinc $(55.5 \mathrm{mmol}, 3.63 \mathrm{~g})$ in dry THF $(60 \mathrm{~mL})$ under argon was added dropwise $\mathrm{TiCl}_{4}(37.0 \mathrm{mmol}, 4.08 \mathrm{~mL})$. The reaction mixture was stirred during $2 \mathrm{~h}$ at $85{ }^{\circ} \mathrm{C}$. A solution of ferrocenecarboxaldehyde $(9.25 \mathrm{mmol}, 1.98 \mathrm{~g})$ and (4-methoxyphenyl) (pyridin-2-yl)methanone $\mathbf{3}$ (9.71 mmol, $2.071 \mathrm{~g})$ in THF $(30 \mathrm{~mL})$ was then added dropwise via a syringe. The reaction mixture was stirred during $8 \mathrm{~min}$ and was controlled by TLC. The reaction was cooled to room temperature and then poured into the water $(100 \mathrm{~mL})$ and extracted with $\mathrm{CH}_{2} \mathrm{Cl}_{2}(3 * 150 \mathrm{~mL})$. The combined organic extracts were dried over anhydrous $\mathrm{MgSO}_{4}$, filtered and concentrated. The oily crude was purified by flash column chromatography on silica gel using a gradient system (cyclohexane/EtOAc 98:2 and then 95:5) to afford the 2-(1-(4-methoxyphenyl)-2 ferrocenylvinyl) pyridine $\mathbf{5}$ in two separable $E$ and $Z$ isomers.

$E$ Isomer 5a: $1.1 \mathrm{~g}$ of an orange solid in $30 \%$ Yield, $\mathrm{Rf}=0.46, \mathrm{SiO}_{2}$ (cyclohexane/EtOAc 80:20). ${ }^{1} \mathrm{H}$ NMR $\left(400 \mathrm{MHz}, \mathrm{CDCl}_{3}\right) \delta$ 8.65-8.60 $(\mathrm{m}, 1 \mathrm{H}$, H12), 7.72 (s, 1H, H13), 7.53-7.46 (m, 1H, H10), $7.20(\mathrm{~d}, \mathrm{~J}=8.7 \mathrm{~Hz}, 2 \mathrm{H}, \mathrm{H} 3, \mathrm{H} 7), 7.12-7.07(\mathrm{~m}, 1 \mathrm{H}$, H11), 7.04 (d, J= 8.7 Hz, 2H, H4, H6), $6.87(\mathrm{~d}, 1 \mathrm{H}$, $\mathrm{J}=8.0 \mathrm{~Hz}, \mathrm{H} 9), 4.14$ (s, 2H, H16, H17), 4.11 (s, 5H, H19), 3.90 (s, 3H, OCH3), 3.87 (s, 2H, H15, $\mathrm{H} 18) .{ }^{13} \mathrm{C} \mathrm{NMR}\left(100 \mathrm{MHz}, \mathrm{CDCl}_{3}\right) \delta 159.1$ (C8),
158.6 (C5), 149.1 (C12), 136.5 (C10), 136.0 (C1), 132.1 (C2), 131.3 (C3, C7), 130.0 (C13), 121.5 (C9), 121.1 (C11), 114.5 (C4, C6), 80.9 (C14), 70.3 (C15, C18), 69.5 (C16, C17), 69.4 (C19), 55.4 (OMe). GC/MS: method 160; Rt $=13.45 \mathrm{~min}, \mathrm{~m} / \mathrm{z}$ $=395[\mathrm{M}](100), 330\left[\mathrm{C}_{19} \mathrm{H}_{16} \mathrm{FeNO}\right]^{+}$(50), 274 $\left[\mathrm{C}_{19} \mathrm{H}_{16} \mathrm{NO}\right]^{+}(30)$. IR (ATR): 3085, $3058\left(v_{\mathrm{Csp} 2-\mathrm{H}}\right)$; 2955, 2929 ( $\left.v_{\text {Csp3-H }}\right) ; 2835$ (vоMe); 1603, 1580, 1507 and $1459\left(v_{\mathrm{C}=\mathrm{C}}\right) ; 1236$ ( $\left.v_{\text {asym C-O-C }}\right) ; 1026\left(v_{\text {sym }}\right.$ C-O-C). HRMS: calcd. for $\mathrm{C}_{24} \mathrm{H}_{21} \mathrm{FeNO}[\mathrm{M}+\mathrm{H}]^{+}$ (396.10453); found (396.10496).

$Z$ Isomer $4 \mathrm{~b}: 1.8 \mathrm{~g}$ of an orange oil $49 \%$ Yield, $\mathrm{R}_{f}=$ $0.23, \mathrm{SiO}_{2}$ (cyclohexane/EtOAc 80:20). ${ }^{1} \mathrm{H}$ NMR $\left(400 \mathrm{MHz}, \mathrm{CDCl}_{3}\right) \delta 8.75(\mathrm{~m}, 1 \mathrm{H}, \mathrm{H} 12), 7.69$ (dd, $\left.J_{\text {ortho }}=7.5 \mathrm{~Hz}, J_{\text {ortho }}=7.6 \mathrm{~Hz}, 1 \mathrm{H}, \mathrm{H} 10\right), 7.30-$ 7.26 (m, 2H, H11, H9), $7.21(\mathrm{~d}, J=8.4 \mathrm{~Hz}, 2 \mathrm{H}$, H3, H7), 6.85 (d, J = 8.4 Hz, 2H, H4, H6), 6.79 (s, 1H, H13), 4.14 (s, 5H, H19), 4.10-4.07 (sbr, 2H, H16, H17), 3.80 (s, 3H, OMe), 3.76-3.73 (sbr, 2H, $\mathrm{H} 15, \mathrm{H} 18) .{ }^{13} \mathrm{C}$ NMR $\left(100 \mathrm{MHz}, \mathrm{CDCl}_{3}\right) \delta 160.1$ (C8), 158.9 (C5), 150.1 (C12), 137.7 (C1), 136.5 (C10), 134.5 (C2), 127.9 (C3, C7), 126.0 (C9 or C11), 125.9 (C13), 122.1 (C9 or C11), 113.9 (C4, C6), 81.8 (C14), 69.3 (C15, C18, C19), 69.0 (C16, C17), $55.4(\mathrm{OMe})$. GC-MS: method 200; $\mathrm{R}_{\mathrm{t}}=$ $11.27 \mathrm{~min}, \mathrm{~m} / \mathrm{z}=395[\mathrm{M}]^{+}(100), 330$ $\left[\mathrm{C}_{19} \mathrm{H}_{16} \mathrm{FeNO}\right]^{+}(55), 274 \quad\left[\mathrm{C}_{19} \mathrm{H}_{16} \mathrm{NO}\right]^{+}(36) . \quad$ IR (ATR): 3081, 3046, $3000\left(v_{\text {Csp2-H }}\right)$; 2956, 2933, 2906 ( $\left.v_{\mathrm{Csp} 3-\mathrm{H}}\right) ; 2836$ ( $\left.\mathrm{v}_{\mathrm{OMe}}\right) ; 1603,1583,1508$ and $1462\left(v_{\mathrm{C}=\mathrm{C}}\right) ; 1243$ ( $\left.v_{\text {asym C-O-C }}\right) ; 1030\left(v_{\text {sym C-O-C }}\right)$. HRMS: calcd. for $\mathrm{C}_{24} \mathrm{H}_{21} \mathrm{FeNO}[\mathrm{M}+\mathrm{H}]^{+}$ (396.10453); found (396.10494).

Minimal Inhibitory Concentration (MIC) and Minimal Bactericidal Concentration (MBC)

All synthesized compounds were tested in triplicate, using microplate dilution method. Minimal inhibitory concentrations (MICs) of compounds were determined according the National Committee for Clinical Laboratory Standard (NCCLS, 2002). The test was performed in sterile 96-well microplates.

The compounds were dissolved in dimethylsulfoxide (DMSO). Serial two fold dilutions of each sample to be evaluated were made to yield volumes of $100 \mu \mathrm{L}$ per well with final concentrations ranging from 100 to 12.5 $\mu \mathrm{g} / \mathrm{mL} .100 \mu \mathrm{L}$ of bacteria suspension with a concentration of $107 \mathrm{CFU} / \mathrm{mL}$ were added to each 
well. Negative control wells contained bacteria only in LB broth medium. After incubation at $30^{\circ} \mathrm{C}$ for $16 \mathrm{~h}$, the minimal inhibitory concentrations (MICs) were recorded as the lowest concentration of compound in the medium that showed no microbial growth. 3-(4,5-dimethyl thiazol-2-yl)2,5-diphenyl tetrazolium bromide (MTT) was added to the wells to facilitate reading of the plates. In case of microbial growth, MTT turns to blue, otherwise the medium remains yellow. Solvent medium and positive growth controls were also run simultaneously. Then from each tube, one loopful was cultured on plate count agar and incubated for $24 \mathrm{~h}$ at $30{ }^{\circ} \mathrm{C}$. The lowest concentration of the compound supporting no colony formation was defined as the MBC.

\section{Conclusions}

We have been involved in the design, synthesis and bioevaluation of new diarylmethanes derivatives 4 and 5 (Fig. 2) using a McMurry coupling reaction. The structural pharmacophore was based on a diarylmethane skeleton containing ferrocene and benzene rings, and compounds exhibited a good antibacterial activity in vitro. In order to optimize the antimicrobial activity of DAMs, we currently investigated the substitution of the aryl group by others aromatic rings and the introduction of the functionalization will be reported in due course.

\section{Acknowledgments}

We gratefully acknowledged Campus France (PHC UTIQUE 2017 37094WH) and the Tunisian Ministry of Higher Education and Scientific Research and Technology for financial support. We are also grateful to Mrs. Fatma Trigui, for her participation to the first preliminary biological tests.

\section{Author Contributions}

All authors contributed to the drafting and revision of the article and approved the final version.

\section{Conflicts of Interest}

The authors declare no conflict of interest.

\section{References}

1- Mondal, S and Panda. G., Synthetic methodologies of achiral diarylmethanols, diaryl and triarylmethanes (TRAMs) and medicinal properties of diaryl and triarylmethanes -an overview. The Royal Society of Chemistry Adv, 2014, 4: p. 2831728358.

2- Nambo, $\mathrm{M}$ and Crudden, C. M., Recent Advances in the syntheis of triarylmethanes by transition metal catalysis. ACS Catalysis, 2015, 5: p. 4734-4742.

3- McCullagh, J.V. and Daggett K.A., Synthesis of triarylmethane and xanthene dyes using electrophilic aromatic substitution reactions. Journal of Chemical Education, 2007, 84: p. 1799-1802.

4- Irie, M., Light-induced reversible pH change. Journal of the American Chemical Society, 1983, 105 : p. 2078-2079.

5- Yan, Q., et al., Near-instant surface-selective fluorogenic protein quantification using sulfonated triarylmethane dyes and fluorogen activating proteins. Organic \& biomolecular chemistry, 2015, 13: p. 2078-2086.

6- Parai, M. K., et al., Thiophene containing triarylmethanes as antitubercular agents. Bioorganic \& Medicinal Chemistry Letters, 2008, 18: p. 289-292.

7- Zeniou, M., Fève, M. et al. Chemical library screening and structure-function relationship studies identify bisacodyl as a potent and selective cytotoxic agent towards quiescent human glioblastoma tumor stem-like cells. PloS one, 2015, 10: e0134793 p.1-35.

8- Rueda, D.C., et al., Identification of dihydrostilbenes in Pholidota chinensis as a new scaffold for GABAA receptor modulators. Bioorganic \& Medicinal Chemistry, 2014, 22: p. 1276-1284.

9- Al-Qawasmeh, R.A., et al., Triaryl methane derivatives as antiproliferative agents. Bioorganic \& Medicinal Chemistry Letters, 2004, 14: p. 347-350.

10- Görmen, M., et al., Ferrocenyl analogues of bisacodyl: Synthesis and antimicrobial activity. Journal of Organometallic Chemistry, 2015, 794: p. 274-281. 
11- Duan, X-F., et al., Insights into general and efficient cross McMurry Reactions between ketones. Journal of Organic Chemistry, 2006, 71: p. 9873-9876.

12- Seto, M, et al., Orally active CCR5 antagonists as anti-HIV-1 agents 2: synthesis and biological activities of anilide derivatives containing a pyridine $N$-oxide moiety. Chemical Pharmaceutical Bulletin, 2004, 52 p: 818-829.

13- Zhang, W. et al., Cesium hydroxidepromoted aerobic oxidation of sec-aromatic alcohols. Tetrahedron Letters, 2008, 49: p.5336-5338.
14- Görmen, M. P. et al.,. Synthesis, Cytotoxicity, and COMPARE Analysis of Ferrocene and [3]Ferrocenophane Tetrasubstituted Olefin Derivatives against Human Cancer Cells. ChemMedChem, 2010, 5: p. 2039-2050.

15- O'Neill A. J. and Chopra I., Preclinical evaluation of novel antibacterial agents by microbiological and molecular techniques. Expert Opinion on Investigational Drugs, 2004, 13: p.1045-1063. 